\title{
Implementasi Metode Penghalusan Ekponensial Tunggal Dalam Prediksi Penjualan Buku
}

\author{
Heri Setyawan'); Sri Hariyati Fitriasih ${ }^{2)}$; Retno Tri Vulandari ${ }^{3)}$ \\ 1,3) Program Studi S1 Informatika, STMIK Sinar Nusantara \\ 2) Progam Studi D3 Sistem Informasi, STMIK Sinar Nusantara \\ 1)heri14500060@gmail.com;2) fitri@sinus.ac.id; 3) retnotv@sinus.ac.id
}

\begin{abstract}
The aim of selling product prediction in the future is to control the amount of existing product stock, so that product shortages or excess stock can be minimized. When the quantity of selling production can be predicted appropriately, the fulfillment of consumer demand can be sought on time and the cooperation of the store with the relationship is maintained well so that the store can avoid losing both sales and consumers. The purpose of this study is to compare the effectiveness of the use of the Single Exponential Smoothing method and Double Exponential Smoothing method with a smoothing parameter value a is 0.5 for forecasting sales by comparing the error values in the two methods using the Mean Squared Error (MSE) method, the MSE results of the Single Exponential Smoothing method is 4967.75 while the MSE Double Exponential Smoothing is 5113.03. Thus, the Single Exponential Smoothing method is more accurate than Double Exponential Smoothing in calculating book sales forecasting because it has a low MSE value.
\end{abstract}

Keywords: Forecasting, Production, Exponential Smoothing, Mean Squance Error.

\section{PENDAHULUAN}

Perbandingan tingkat keefektifan peramalan khususnya pada penjualan, dapat sangat mudah dilakukan, karena manusia mampu dapat untuk mengetahui nilai terbaik dari apa yang dibandingkan. Ketika pemilik usaha tidak dapat memanfaatkan teknologi infomasi, maka banyak informasi yang terbuang percuma. Bentuk laporan yang masih manual membuat pemilik menjadi kesulitan dalam melihat perkembangan usaha, akibatnya pemilik dapat melakukan kesalahan dalam pengambilan keputusan terutama untuk penambahan atau pengurangan stok barang.

Tujuan dari penelitian ini adalah untuk membandingkan keefektifan penggunaan metode Single Exponential Smoothing dan metode Double Exponential Smoothing untuk peramalan penjualan buku pada Toko Buku Sembilan. Pengukuran dilakukan dengan mengevaluasi hasil peramalan yaitu dengan menggunakan metode Mean Squared Error (MSE). Dengan menggunakan MSE, error yang ada menunjukkan seberapa besar perbedaan hasil estimasi dengan hasil yang akan diestimasi. antara metode SES (Single Exponential Smoothing) dan DES (Double Exponential Smoothing). Mean Squared Error (MSE) sebagai alternative untuk mengevaluasi teknik peramalan masing - masing kesalahan. Metode MSE juga sebagai indikator yang berguna dan memberikan nilai absolut sabagai kebalikan dari informasi relative dalam metode
MAPE. Hasil akhir dari penelitian ini berupa Perbandingan Tingkat Akurasi antara metode SES (Single Exponential Smoothing) dan DES (Double Exponential Smoothing) yang nantinya akan menghasilkan nilai peramalan terbaik setiap periode dan mengetahui metode manakah yang lebih efektif untuk peramalan penjualan .

Dengan demikian diharapkan analisis penyebab peningkatan dan penurunan penjualan ini dapat dijadikan evaluasi untuk terus meningkatkan penjualan produk. Untuk itu dilakukan penelitian tentang "Perbandingan Metode Single Exponential Smoothing dan Double Exponential Smoothing Dalam Prediksi Penjualan Buku Pada Toko Buku Sembilan".

\section{TINJAUAN PUSTAKA \\ 2.1 Peramalan (Forcasting)}

Peramalan merupakan sebuah langkah dapat di tempuh untuk memperoleh prediksi terhadap kejadian di masa mendatang. Forecasting (peramalan) adalah suatu unsur yang sangat penting dalam pengambilan keputusan. Peramalan serial data yang dilakukan umumnya akan berdasarkan pada data masa lampau yang dianalisis dengan menggunakan cara-cara tertentu [1].

Data masa lampau dikumpulkan, dipelajari, dan dianalisis dihubungkan dengan perjalanan waktu dan mencoba mengatakan sesuatu yang akan terjadi di masa mendatang. Akurasi suatu ramalan berbeda untuk setiap persoalan dan 
berbagai faktor, akurasi peramalan tidak akan selalu didapatkan hasil ramalan dengan ketepatan $100 \%$, namun demikian tidak berarti bahwa ramalan menjadi tidak penting. Pada dasarnya tidak ada teknik yang dapat menghasilkan ramalan yang sangat akurat (yaitu masa yang akan datang tidak mungkin dapat diramalkan secarat epat dan sempurna). Karena itu keandalan ramalan digunakan untuk melihat seberapa andal / akuratnya suatu metode peramalan [2].

\subsection{Exponential Smoothing}

Exponential Smoothing adalah mengambil rata-rata dari nilai pada beberapa periode untuk menaksir nilai pada suatu periode, exponential smoothing adalah suatu peramalan rata-rata bergerak yang melakukan pembobotan menurun secara exponential terhadap nilai-nilai observasi yang lebih tua Pemetaan [3].

\section{Exponential Smoothing}

Juga dikenal sebagai simple exponential smoothing (SES) yang digunakan pada peramalan jangka pendek, biyasanya hanya 1 bulan kedepan [4] [5]. Model mengasumsikan bahwa data berfluktuasi di sekitar nilai mean yang tetap, tanpa trend atau pola pertumbuhan konsisten. Metode SES ditentukan menggunaan Persamaan (1).

$$
\begin{aligned}
& S_{t}^{\prime}=\alpha^{*} X_{t}+(1-\alpha)^{*} S_{t-1}^{\prime} \\
& S^{\prime}{ }_{t} \quad \text { : Ramalan untuk periode ke } \mathrm{t}+1 \\
& X_{t} \quad \text { : Nilai riil periode ke } \mathrm{t} \\
& t \quad \text { : Jangka waktu rata-rata bergerak } \\
& \alpha \quad \text { : konstanta perataan antara } 0 \text { dan } 1
\end{aligned}
$$

\section{Double Exponential Smoothing}

Metode ini digunakan ketika data menunjukan adanya terend. Exponential smoothing dengan adanya trend seperti pemulusan sederhana kecuali bahwa dua komponen harus diupdate setiap periode ,level dan trendnya. Level adalah estimasi yang dimuluskan dari nilai data pada akhir masing-masing periode. Trend adalah estimasi yang dihaluskan dari pertumbuhan rata-rata pada akhir masing-masing periode [6]. DES ditentukan menggunaan rumus berikut :

$S^{\prime}{ }_{t}=\alpha^{*} X_{t}+(1-\alpha)^{*} S^{\prime}{ }_{t-1}$

$S^{\prime \prime}{ }_{t}=2 S^{\prime}{ }_{t}+(1-\alpha)^{*} S^{\prime \prime}{ }_{t-1}$

$a_{t}=\alpha 2 S^{\prime}{ }_{t}-S^{\prime \prime}{ }_{t-1}$

$b_{t}=\frac{a}{1-a}+\left(S^{\prime}{ }_{t}-S^{\prime \prime}{ }_{t}\right)$

$F_{t+m}=a_{t}+b_{t} m$

$F_{t+m}$ : hasil peramalan ke-m

$S^{\prime}{ }_{t} \quad$ : Nilai pemulusan exponential tunggal
$S^{\prime \prime}{ }_{t} \quad$ : Nilai pemulusan exponential ganda

$b_{t}, a_{t}$ : Konstanta pemulusan

a : Parameter pertama perataan antara nol dan 1 untuk pemulusan nilai observasi

$m \quad$ : jumlah periode ke muka yang akan diramalkan.

\subsection{Mean Squared Error (MSE)}

Cara yang cukup sering digunakan dalam mengevaluasi hasil peramalan yaitu dengan menggunakan metode Mean Squared Error (MSE). Dengan menggunakan MSE, error yang ada menunjukkan seberapa besar perbedaan hasil estimasi dengan hasil yang akan diestimasi. MSE cenderung menonjolkan deviasi yang besar karena adanya pengkuadratan [7]. Persamaan (7) digunakan untuk menghitung MSE.

$$
\begin{array}{ll}
\text { MSE }= & \frac{1}{n} \sum_{t=1}^{n}\left(X_{t}-F_{t}\right)^{2} \\
X_{t} & =\text { data aktual pada periode ke } t \\
F_{t} & =\text { nilai ramalan pada periode ke-t } \\
n & =\text { banyaknya periode waktu }
\end{array}
$$

\subsection{Penelitian Terkait Metode Single Exponential Smoothing}

Single exponential smoothing digunakan pada peramalan jangka pendek, biasanya hanya 1 bulan ke depan. Pola data yang tidak stabil atau perubahannya besar dan bergejolak. Metode Single Exponential Smoothing lebih cocok digunakan untuk meramalkan hal-hal yang fluktuasinya secara acak (tidak teratur). Metode tersebut menggunakan pencatatan data masa lalu yang sangat sedikit. Dalam hal itu mengasumsikan bahwa data berfluktuasi di sekitar nilai rata-rata yang tetap, tanpa mengikuti pola atau tren [8]. Sedangkan metode double exponential smoothing. Metode tersebut merupakan model linier yang dikemukakan oleh Brown. Di dalam metode Double Exponential Smoothing dilakukan proses smoothing dua kali. Kekurangan dari metode ini adalah harus dilakukan maintenance berkala dan pengecekan rutin dengan cara pemerikasaan kembali apakah data - data yang sudah dimasukan sudah benar atau ada kesalahan, melakukan update aplikasi jika ada bug atau penambahan fitur baru yang dirasa penting. Untuk mendapatkan permalan stok barang yang akurat harus memiliki banyak data penjualan barang per-bulannya [9].

Berkaitan dengan dua hal tersebut, penulis membandingkan kedua metode untuk mengetahui penggunaan metode Single 
Exponential Smoothing dan metode Double Exponential Smoothing serta membandingkan keefektifan penggunaan kedua metode tersebut Dengan harapan mengetahui metode mana yang paling akurat untuk peramalan penjualan keseluruhan dari merek buku. Pengukuran dilakukan dengan mengevaluasi hasil peramalan yaitu dengan menggunakan metode Mean Squared Error (MSE).

\section{METODE PENELITIAN}

\subsection{Prosedur dan Pengumpulan Data}

1. Jenis Data

Dalam penelitian ini penulis menggunakan penelitian kuantitatif, karena data yang diperoleh nantinya berupa angka. Dari angka yang diperoleh akan dianalisis lebih lanjut dalam analisis data. Data kuantitatif yang diambil meliputi data penjualan buku, harga buku, dan macam buku pada Toko Buku Sembilan.

2. Sumber Data

- Data primer yang diperoleh yaitu dari wawancara kepada Pemilik dan karyawan dari Toko Buku Sembilan secara langsung ataupun tidak langsung mengenai data penjualan pada toko tersebut berupa jenis produk buku, harga barang, dan data penjualan dalam setiap bulan.

- Dalam penelitian ini yang menjadi sumber data sekunder yaitu literatur, artikel, jurnal serta situs di internet yang berkenaan dengan penelitian yang dilakukan.

\subsection{Pengumpulan Data}

1. Studi Literatur

Pada tahap ini peneliti mengumpulkan informasi dan mempelajari materi serta sumber-sumber data yang diperlukan untuk membangun sistem aplikasi peramalan dengan membandingkan metode Single Exponential Smoothing dan Double Exponential Smoothing berdasarkan datadata yang telah diberikan.

\section{Wawancara}

Melakukan tanya jawab dengan Pemilik Toko dan karyawan sebagai obyek penelitian untuk mendata proses penjualan di Toko Buku Sembilan untuk meyakinkan bahwa data yang diperoleh benar-benar akurat. Data didukung data jenis buku yang dijual, harga buku dari masing - masing jenis dan data penjualan selama periode per bulannya.

\subsection{Desain Sistem}

\section{Use Case Diagram}

Interaksi antara pemilik toko dan karyawan atau pengelola data untuk memodelkan dan menyatakan unit fungsi/layanan yang disediakan oleh sistem, seperti bagian admin dalam aktivitas penjualan, update produksi dan penjualan barang, peramalan, serta hasil perbandingan dari metode yang digunakan.

2. Diagram Class

Pada penelitian ini, Diagram Class Memberikan klasifikasikan class - class pada sistem dari data penjualan seperti class admin, data produk, penjualan,dan perbandingan, validasi, koneksi database, antarmuka dan main. Agar terhubung satu sama lain sehingga menghasilakan suatu aplikasi peramalan.

3. Sequence Diagram

Dari aplikasi yang dibuat, Sequence Diagram menjelaskan/ menggambarkan interaksi object yang disusun dalam suatu urutan waktu dan memperlihatkan tahap demi tahap apa yang seharusnya terjadi untuk menghasilkan sesuatu yang dilakukan dalam use case. Yaitu seperti Sequence diagram otentikasi user, Sequence diagram data produk, Sequence diagram penjualan, dan Sequence diagram perbandingan.

4. Activity Diagram

Activity diagram yang diterapkan yaitu dengan memodelkan event-event yang terjadi dalam suatu Use Case. Dan juga membentuk flow diagram yang memodelkan alur kerja (workflow) sebuah proses bisnis dan urutan aktivitas sebuah proses. Activity diagram yang diterapkan seperti Activity diagram untuk otentikasi user, Activity diagram data produk, Activity data penjualan, dan Activity diagram perbandingan peramalan kuantitas penjualan.

\subsection{Pengujian Sistem}

Proses selanjutnya adalah pengujian program, program yang telah dibangun akan diuji untuk mengetahui apakah program tersebut berjalan dengan benar dan sesuai dengan perancangan yang dilakukan.

1. Pengujian Fungsional

Pengujian fungsionalitas dilakukan dengan menggunakan metode blackbox testing yaitu untuk mencari kesalahan dan kekurangan dari sistem yang telah dibuat 
untuk kemudian dilakukan perbaikan dan penyempurnaan sistem.

2. Pengujian Validitas

Cara yang cukup sering digunakan dalam mengevaluasi hasil peramalan yaitu dengan menggunakan metode Mean Squared Error (MSE). Dengan menggunakan MSE, error yang ada menunjukkan seberapa besar perbedaan hasil estimasi dengan hasil yang akan diestimasi. Hal yang membuat berbeda karena adanya fluktuasi pada data atau karena tidak mengandung estimasi yang lebih akurat. MSE cenderung menonjolkan deviasi yang besar karena adanya pengkuadratan. Mean Squared Error (MSE) adalah metode alternative untuk mengevaluasi teknik peramalan masing masing kesalahan [10].

\subsection{Implementasi}

Implementasi aplikasi menerapkan perbadingan metode single exponential smoothing dan double exponential smoothing dalam prediksi penjualan buku berupa aplikasi web.

\section{PEMBAHASAN}

\subsection{Analisa peramalan dan perbandingan}

Pada penelitian ini langkah pertama yang perlu dilakukan yaitu pengumpulkan data dan menentukan data yang akan diolah untuk proses perbandingan menggunakan metode Single Exponential Smoothing dan Double Exponential Smoothing. Pada kedua metode ini peramalan dilakukan dengan mengulang perhitungan menggunakan data terbaru, dimana setiap data diberi bobot. Bobot ini berfungsi untuk melakukan penghalusan terhadap nilai peramalan. Besarnya a (alpha) ditentukan secara error sampai ditemukan a (alpha) yang menghasilkan forecast error terkecil. Besarnya a adalah antara 0 dan 1. Pada contoh perhitungan akan dihitung peramalan dengan bobot atau $\alpha=0,9$ karena dari perhitungan $\alpha$ yang telah dilakukan antara 0 sampai 1 , yang memililiki nilai eror terendah adalah 0,9 . Pengukuran dilakukan dengan mengevaluasi hasil peramalan yaitu dengan menggunakan metode Mean Squared Error (MSE).

\subsection{Metode Single Exponential Smoothing} Metode Single Exponential Smoothing ini akan diterapkan pada perhitungan dalam menentukan jumlah penjualan buku yang akan di jual untuk bulan selanjutnya. Rumus yang digunakan untuk metode Single Exponential Smoothing dapat dilihat pada Persamaan (1). Dalam contoh perhitungan peramalan kali ini, akan menggunakan semua nilai $\alpha$ (alpha) yaitu $(\alpha=0,9)$ Data yang akan dianalisis hanya diambil satu buku sebagai sample yaitu buku Bahasa Indonesia Wajib Platinum . Tabel 1 menunjukkan Data Aktual penjualan buku Bahasa Indonesia wajib untuk SMA penerbit Platinum.

Tabel 1. Data Penjualan Buku

\begin{tabular}{|c|c|c|}
\hline \multirow{2}{*}{ No } & \multirow{2}{*}{ Periode } & \begin{tabular}{c} 
Data Penjualan \\
\cline { 3 - 3 }
\end{tabular} \\
\cline { 3 - 3 } & $\begin{array}{c}\text { Bahasa } \\
\text { Indonesia } \\
\text { Waiib }\end{array}$ \\
\hline 1 & Januari 2018 & 26 \\
\hline 2 & Februari2018 & 23 \\
\hline 3 & Maret2018 & 49 \\
\hline 4 & April 2018 & 57 \\
\hline 5 & Mei 2018 & 41 \\
\hline 6 & Juni 2018 & 78 \\
\hline 7 & Jull 2018 & 98 \\
\hline 8 & Aqus 2018 & 290 \\
\hline 9 & Sept 2018 & 300 \\
\hline 10 & Okto 2018 & 255 \\
\hline 11 & Nov 2018 & 175 \\
\hline 12 & Des 2018 & 64 \\
\hline 13 & Januari 2019 & \\
\hline
\end{tabular}

Berikut contoh perhitungan untuk alpha ( $\alpha$ $=0,9)$.

$$
\begin{aligned}
S_{2}{ }^{\prime}= & \alpha^{*} X_{1}+(1-\alpha)^{\star} S^{\prime}{ }_{t-1} \\
& =0,9 \times 26+(1-0,9) \times 26 \\
& =23,4+2,6 \\
& =26 \\
S_{3}{ }^{\prime}= & \alpha^{*} X_{2}+(1-\alpha)^{\star} S^{\prime}{ }_{t-1} \\
& =0.9 \times 23+(1-0.9) \times 26 \\
& =20,7+2,6 \\
& =23,3 \\
S_{4}{ }^{\prime}= & \alpha^{*} X_{3}+(1-\alpha)^{\star} S^{\prime}{ }_{t-1} \\
& =0.9 \times 49+(1-0.9) \times 23,3 \\
& =44,1+2,33 \\
& =46,43
\end{aligned}
$$

Tabel 2 Hasil Peramalan Buku Bahasa Indonesia Wajib SMA

\begin{tabular}{|c|c|c|c|}
\hline No & Periode & $\begin{array}{c}\text { Data } \\
\text { Penjualan }\left(X_{f}\right)\end{array}$ & $S_{z}^{\prime}$ \\
\hline 1 & Januari 2018 & 26 & 26 \\
\hline 2 & Februari2018 & 23 & 26 \\
\hline 3 & Maret2018 & 49 & 23.30 \\
\hline 4 & April 2018 & 57 & 46.43 \\
\hline 5 & Mei 2018 & 41 & 55.94 \\
\hline 6 & Juni 2018 & 78 & 42.49 \\
\hline 7 & Juli 2018 & 98 & 74.45 \\
\hline 8 & Agus 2018 & 290 & 95.64 \\
\hline 9 & Sept 2018 & 300 & 270.56 \\
\hline 10 & Okto 2018 & 255 & 297.06 \\
\hline 11 & Nov 2018 & 175 & 259.21 \\
\hline 12 & Des 2018 & 64 & 183.42 \\
\hline 13 & Januari 2019 & & 75.94 \\
\hline
\end{tabular}


Tabel 2 menunjukkan hasil perhitungan keseluruhan dengan $\alpha$ (alpha) 0,9. Proses perhitungan ini dilakukan secara beruntun dan mendapat hasil peramalan akhir pada bulan januari 2019 dengan hasil ramalan 75,94.

\subsection{Metode Double Exponential Smoothing}

Metode Single Exponential Smoothing ini akan diterapkan pada perhitungan dalam menentukan jumlah penjualan buku yang akan dijual untuk bulan selanjutnya. Rumus yang digunakan untuk metode Single Exponential Smoothing dapat dilihat pada Persamaan (3), (4), (5), (6). Dalam contoh perhitungan peramalan kali ini, akan menggunakan nilai $\alpha$ (alpha) yaitu $(\alpha=0,9)$ Data yang akan dianalisis hanya diambil satu jenis buku sebagai sample yaitu buku Bahasa Indonesia Wajib SMA kelas 3 penerbit Platinum. Tabel menunjukkan Data Aktual penjualan buku Bahasa Indonesia Wajib. Perhitungan Metode DES adalah:

$$
\begin{aligned}
S_{2}{ }^{\prime \prime}=\alpha & { }^{*} S_{2} \quad+(1-\alpha)^{*} S_{1}{ }^{\prime \prime} \\
& =0,9 \times 26+(1-0,9) 26 \\
& =23,4+2,6 \\
& =26,00 \\
S_{3}{ }^{\prime \prime}=\alpha & { }^{\prime} \quad+(1-\alpha)^{*} S_{2}{ }^{\prime \prime} \\
& =0,9 \times 23,3+(1-0,9) 26 \\
& =20,97+2,6 \\
& =23,57 \\
S_{4}{ }^{\prime \prime}=\alpha & { }^{\prime} \quad+(1-\alpha)^{*} S_{3}{ }^{\prime \prime} \\
& =0,9 \times 46,43+(1-0,9) 23,57 \\
& =41,78+2,35 \\
& =44,14
\end{aligned}
$$

Mencari $a_{t}$

$$
\begin{aligned}
a_{2} & =a^{\star} 2 S_{2}{ }^{\prime}-S_{2}{ }^{\prime \prime} \\
& =2 \times 26-26 \\
& =26 \\
a_{3} & =a^{\star} 2 S_{3}{ }^{\prime}-S_{3}{ }^{\prime \prime} \\
& =2 \times 23,30-23,57 \\
& =23,03 \\
a_{4} & =a^{\star} 2 S_{4}{ }^{\prime}-S_{4}{ }^{\prime \prime} \\
& =2 \times 46,43-44,14 \\
& =48,72
\end{aligned}
$$

\section{Mencari $b_{t}$}

$$
\begin{aligned}
b_{2} & =\frac{a}{1-a} \times\left(S_{2}{ }^{\prime}-S_{2}{ }^{\prime \prime}\right) \\
& =\frac{0,9}{1-0,9} \times(26-26) \\
& =0 \\
b_{3} & =\frac{a}{1-a} \times\left(S_{3}{ }^{\prime}-S_{3}{ }^{\prime \prime}\right) \\
& =\frac{0,9}{1-0,9} \times(23,30-23,57) \\
& =-2.43 \\
b_{4} & =\frac{a}{1-a} \times\left(S_{4}{ }^{\prime}-S_{4}{ }^{\prime \prime}\right) \\
& =\frac{0,9}{1-0,9} \times(46,43-44,14) \\
& =20,57
\end{aligned}
$$

Tabel 3. Hasil peramalan metode DES

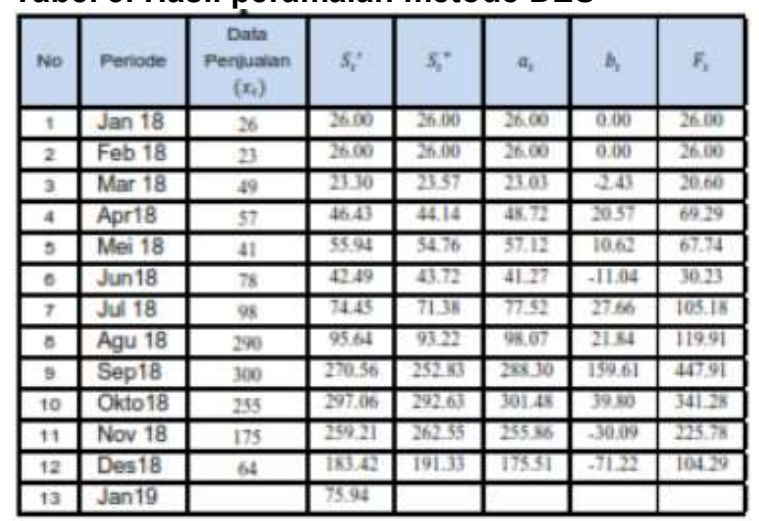

Tabel 3 menunjukkan hasil perhitungan keseluruhan dari metode DES dengan a (alpha) 0,9 . Proses perhitungan ini dilakukan secara beruntun dan mendapat hasil peramalan akhir pada bulan Januari 2019 dengan hasil ramalan $104,29$.

\subsection{Desain Sistem}

Tahap perancangan sistem ini menjelaskan model dari program yang dibangun, penulis menggunakan UnifiedModeling Language (UML) yang terdiri dariusecase diagram, class diagram, sequencediagram dan activity diagram.

\section{Use Case Diagram}

Use case diagram digunakan untuk memodelkan dan menyatakan unit fungsi layanan yang disediakan oleh sistem. Use Case diagram juga menjelaskan mengenai aktoraktor yang terlibat dengan perangkat lunak yang dibangun beserta proses-proses yang ada didalamnya. Berikut Gambar 1 adalah use case diagram sistem.

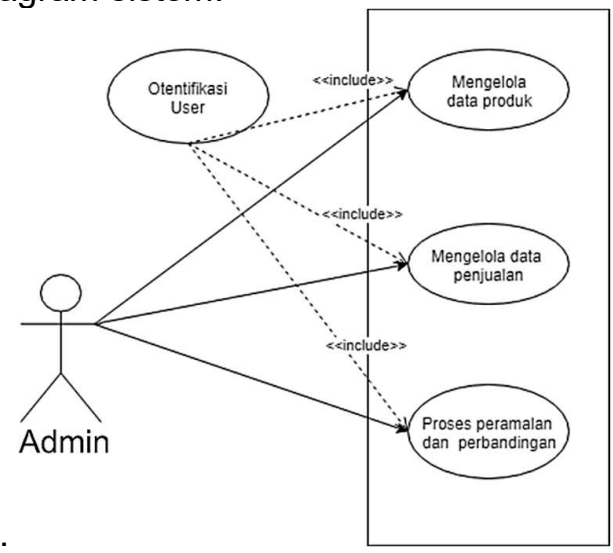

Gambar 1. Use Case Diagram

\section{Activity Diagram}

Activity Diagram menggambarkan workflow (aliran kerja) atau aktivitas dari sebuah sistem atau proses bisnis atau menu yang ada pada perangkat lunak. Activity Diagram pada aplikasi 
ini, mendefinisikan rancangan menu yang ditampilkan pada aplikasi. Berikut ini adalah gambaran Activity Diagram

Pada diagram activity peramalan, admin akan membuka form peramalan dan perbandingan lalu memilih merk produk yang akan diramal, dan meng-input waktu dan nilai apha peramalan yang akan diramal. Kemudian di proses dengan menggunakan metode Single Exponential Smoothing dan Double Exponential Smoothing. Setelah itu sistem akan menghitung peramalan dan nilai kesalahan/eror dengan menggunakan metode MSE.

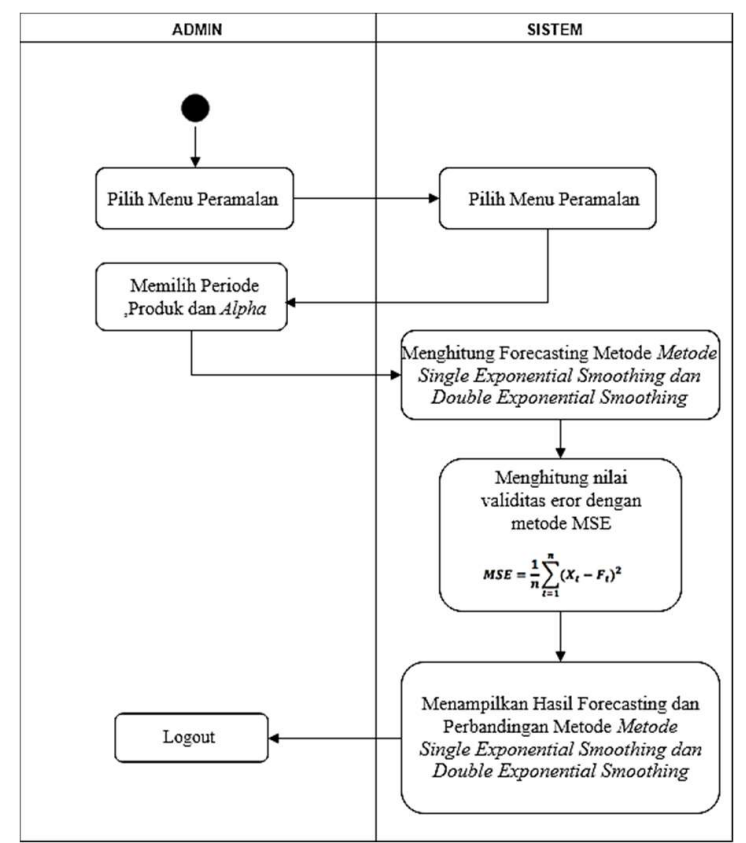

Gambar 2 Activity Diagram Perbandingan Penjualan

\section{Sequence Diagram Perbandingan}

Proses yang terjadi pada proses forecasting yaitu, admin terlebih dahulu memilih produk dan waktu peramalan, tekan tombol proses maka sistem akan melakukan proses perhitungan peramalan dan perbandingan dengan metode Single Exponential Smoothing dan Double Exponential Smoothing. perhitungan validitas atau nilai error dengan metode MSE. Proses dapat dilihat pada Gambar 3 Sequence diagram perbandingan.

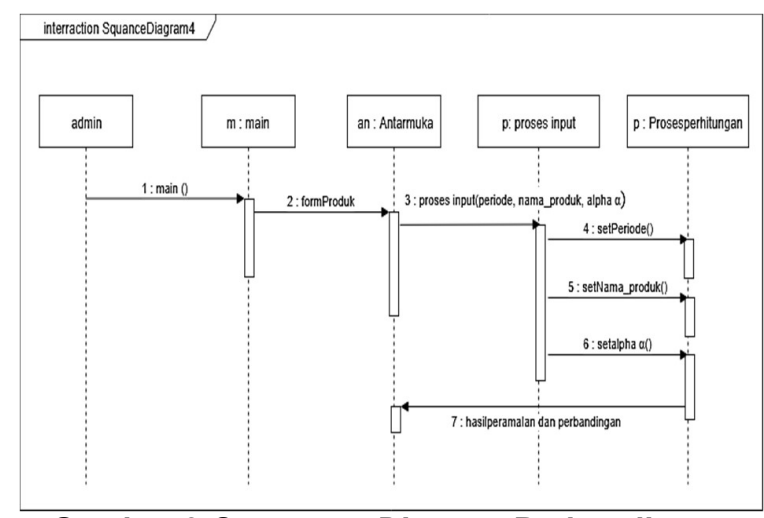

Gambar 3 Sequence Diagram Perbandingan

\section{Class Diagram}

Class diagram menggambarkan struktur sistem dari segi pendefinisian kelas - kelas yang akan dibuat untuk membangun sistem. Kelas memiliki atribut dan metode atau operasi. Atribut merupakan variabel - variabel yang dimiliki suatu kelas. Metode merupakan fungsi - fungsi yang dimiliki oleh suatu kelas. Class diagram pada aplikasi ini digambarkan pada Gambar 4 yaitu sebagai berikut.

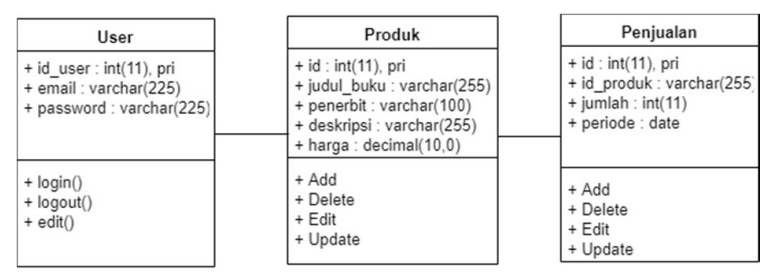

Gambar 4 Class Diagram Sistem

\subsection{Pengujian Sistem}

1. Pengujian Validitas

Untuk menentukan pebandingan metode Single Exponential Smoothing dan Double Exponential Smoothing. Maka diperlukan pengujian validitas yang beguna untuk menentukan nilai uji yang tepat. Pada penelitian ini pengujian validitas menggunakan metode Mean Squared Error (MSE). Dengan menggunakan MSE, error yang ada menunjukkan seberapa besar perbedaan hasil estimasi dengan hasil yang akan diestimasi. Hal yang membuat berbeda karena adanya fluktuasi pada data atau karena tidak mengandung estimasi yang lebih akurat. MSE cenderung menonjolkan deviasi yang besar karena adanya pengkuadratan. Mean Squared Error (MSE) adalah metode alternative untuk mengevaluasi teknik peramalan masingmasing kesalahan. Metode MSE merupakan indikator yang berguna dan memberikan nilai absolut sabagai kebalikan dari informasi relative dalam metode MAPE. 
Tabel 4 Nilai validasi Mean Sequare Error (MSE) Metode Single Exponential Smoothing

\begin{tabular}{|c|c|c|c|c|c|}
\hline No & Periode & $\begin{array}{c}\text { Data } \\
\text { Penjualan }\end{array}$ & $S_{t}^{\prime}$ & $x_{t}-S_{t}$ & $\begin{array}{l}\left(x_{t}-\right. \\
\left.s_{t}\right) 2\end{array}$ \\
\hline 1 & $\operatorname{Jan} 18$ & 26 & 20.00 & 0.00 & 0.00 \\
\hline 2 & Feb 18 & 23 & 20.00 & -3.00 & 9.00 \\
\hline 3 & Mar 18 & 45 & 23.30 & 25.70 & 660.40 \\
\hline 4 & Apr 18 & 57 & 46.43 & 10.57 & 111.72 \\
\hline 5 & Mei 18 & 41 & 95.94 & -14.94 & 223.29 \\
\hline 6 & Jun18 & 70 & 42.43 & 30.51 & 1260.65 \\
\hline 7 & Jul 18 & 96 & 74.45 & 23.55 & 504.63 \\
\hline 8 & Agu 18 & 2000 & 95.04 & 134.36 & 377 . \\
\hline 9 & Sep18 & 300 & 270.50 & 29.44 & 800.45 \\
\hline 10 & Okto18 & 250 & 297.06 & -42.00 & 1700.74 \\
\hline 11 & Nov 18 & 175 & 250.21 & -8421 & 7090.58 \\
\hline 12 & Des18 & 64 & 103.42 & -119.42 & 14261.27 \\
\hline 13 & $\operatorname{Jan} 19$ & & 75.94 & & \\
\hline & & & & $\sum\left(x_{1}-f_{n}\right)^{2}$ & 04580.74 \\
\hline
\end{tabular}

Perhitungan metode MSE pada forecast dengan alpha $=0,9$

$$
\begin{aligned}
& \text { MSE }=\frac{\sum\left(x_{\boldsymbol{t}}-\boldsymbol{S}_{\boldsymbol{t}}\right) \mathbf{2}}{n} \\
& =\frac{64580.74}{12} \\
& =4967.75
\end{aligned}
$$

Tabel 5 Nilai validasi Mean Sequare Error (MSE) Metode Single Exponential Smoothing

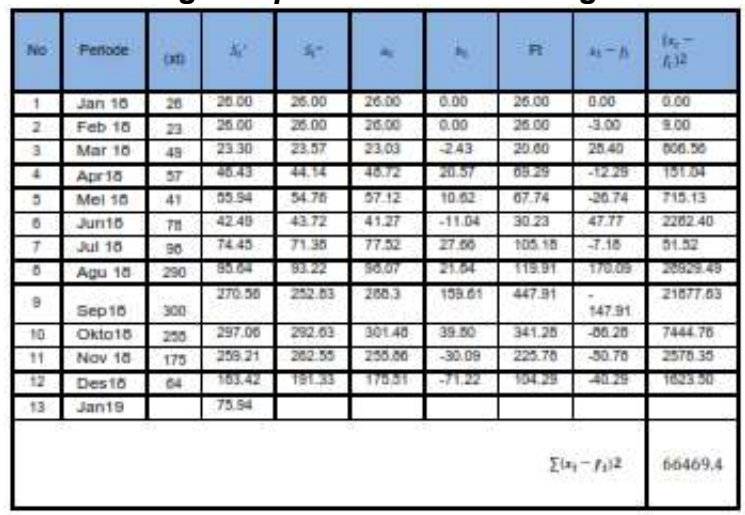

Perhitungan metode MSE pada forecast dengan alpha $=0,9$

$$
\begin{aligned}
\text { MSE } & =\frac{\sum\left(x_{t}-f_{t}\right) 2}{n} \\
& =\frac{66469.4}{12} \\
& =5113.03
\end{aligned}
$$

\section{Analisa Perbandingan}

Berdasarkan Tabel 4 dan Tabel 5 dapat dilihat perbandingan fluktuasi yang terbentuk antara metode peramalan yang digunakan dengan data aktual menunjukkan terdapatnya error. Dari hasil perhitungan menunjukkan bahwa, pada tabel 4 merupakan tabel hasil peramalan dan perhitungan metode Single Exponential Smoothing. Dilihat pada tabel , (S') merupakan nilai peramalan dari metode Single Exponential Smoothing. Dilihat pada Tabel 4, (S') merupakan nilai peramalan dari metode Single Exponential Smoothing. Pada kolom ke-14, baris ke-3, menunjukkan hasil nilai peramalan periode yang diramalkan berikutnya yaitu bulan januari tahun 2019 sebesar 75,94. Kemudian untuk menentukan perbandingan, perlu adanya pengujian validitas yaitu menggunakan Mean Sequare Error (MSE) guna menentukan nilai error terendah dari kedua metode. Pada Tabel 4 kolom ke-15, baris ke-6 menunjukkan nilai dari jumlah seluruh data peramalan metode Single Exponential Smoothing, yang di peroleh dari pengkuadratan dari data aktual $\left(x_{t}\right)$ dan data hasil peramalan $\left(S_{t}\right)$, yang kemudian dibagi dengan jumlah data ( $n$ ). sehingga menghasilkan nilai validitas metode Single Exponential Smoothing yaitu 4967,75.

Dilihat pada Tabel 5, merupakan tabel hasil peramalan dan perhitungan metode Double Exponential Smoothing. (S") menunjukkan nilai dari peramalan ganda (duoble), berbeda dengan metode Single Exponential Smoothing. Untuk menentukan hasil peramalan dari metode Double Exponential Smoothing, harus melalui penyesuaian Exponential Smoothing tungal dengan perbedaan $\left(a_{t}\right)$ dan Estimasi kecenderungan dari periode waktu satu ke periode waktu berikutnya $\left(b_{t}\right)$. Sehingga akan menghasilkan nilai permalan Double Exponential Smoothing $\left(F_{t}\right)$, pada periode berikutnya. Dilihat pada tabel 5 pada kolom ke13 , baris ke-8, menunjukan hasil peramalan dari metode Double Exponential Smoothing $\left(F_{t}\right)$ yaitu 104,29. Kemudian seperti pada pernyataan sebelumnya, untuk menentukan perbandingan, perlu adanya pengujian validitas yaitu menggunakan Mean Sequare Error (MSE) guna menentukan nilai error terendah dari kedua metode. Pada tabel 5 kolom ke-15, baris ke-10 menunjukkan nilai dari jumlah seluruh data peramalan metode Double Exponential Smoothing, yang di peroleh dari pengkuadratan dari data aktual $\left(x_{t}\right)$ dan data hasil peramalan $\left(F_{t}\right)$, yang kemudian dibagi dengan jumlah data $(n)$. sehingga menghasilkan nilai validitas metode Double Exponential Smoothing yaitu 5113,03 . Hasil perhitungan dapat dilihat pada Tabel 6.

Tabel 6. Hasil Perbandingan

\begin{tabular}{|l|c|c|}
\hline \multicolumn{1}{|c|}{ Metode } & Alpha & MSE \\
\hline $\begin{array}{l}\text { Single Exponential } \\
\text { Smoothing }\end{array}$ & 0,9 & 4967,75 \\
\hline $\begin{array}{l}\text { Double Exponential } \\
\text { Smoothing }\end{array}$ & 0,9 & 5113,03 \\
\hline
\end{tabular}


Berdasarkan Tabel 6, dapat dilihat bahwa metode Single Exponential Smoothing dengan menghasilkan nilai error (MSE) terkecil apabila dibandingkan dengan metode Double Exponential Smoothing. Sehingga dapat lihat bahwa metode Single Exponential Smoothing dengan alpha $=0,9$ merupakan metode yang efektif digunakan untuk meramalkan penjualan buku pada Toko Buku Sembilan pada periode (bulan) berikutnya.

\subsection{Implementasi Antarmuka}

Implementasi antarmuka dalam aplikasi ini berupa tampilan web yang terdiri dari hamalan admin, data produk, data penjualan, dan halaman perbandingan metode dapat dilihat sebagai berikut :

1. Halaman Admin

Form halaman admin merupakan tampilan antarmuka yang muncul ketika proses autentifikasi username dan password pada login telah divalidasi. Pada form halaman utama ini terdapat 4 menu utama yaitu menu Beranda, data produk, data penjualan, dan perbandingan.

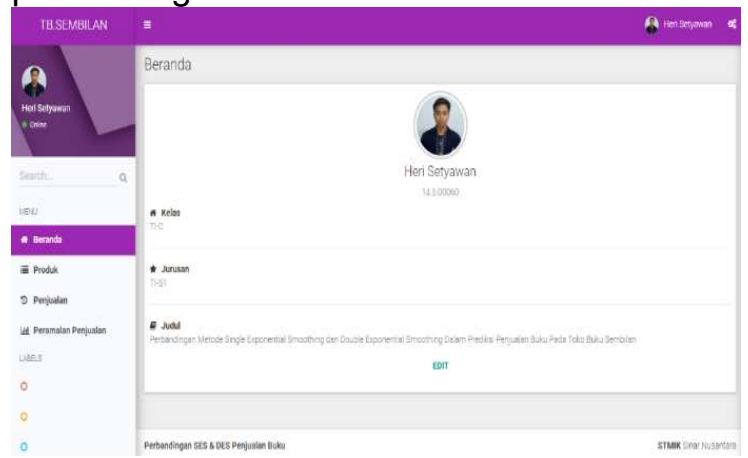

Gambar 5 Tampilan Halaman Utama

2. Halaman Data Produk

Tampilan menu data produk yang berfungsi untuk menampilkan judul, penerbit, diskripsi dan harga buku yang terdapat pada Toko Buku Sembilan.

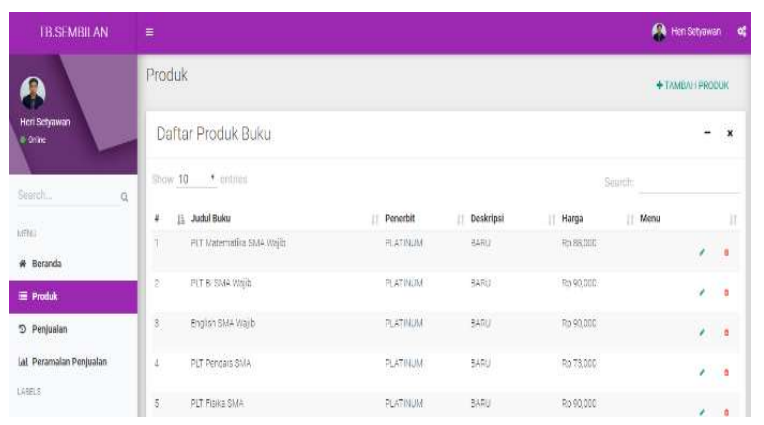

Gambar 6 Tampilan Halaman data produk
3. Halaman data penjualan

Tampilan menu penjualan yang berfungsi untuk menampilkan jumlah buku yang terjual sesuai dengan jenis buku pada Toko Buku Sembilan dan merupakan data masa lalu yang digunakan dalam proses forecasting.

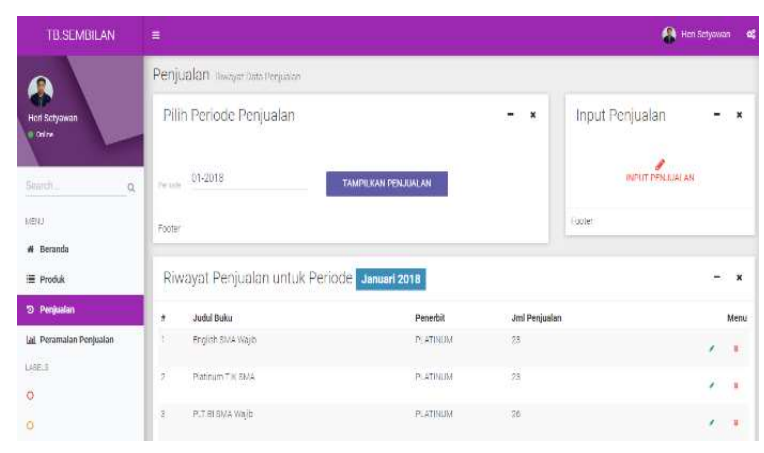

Gambar 7 Tampilan Halaman data produk

4. Halaman perbandingan

Pada menu forecasting ini admin dapat melakukan proses peramalan. Terlebih dahulu admin harus memilih jenis produk yang akan diramalkan kemudian memilih bulan yang akan diramalkan lalu tekan ok. Data peramalan akan otomatis tersimpan di database dan akan muncul di tabel forecasting. Tampilan halaman perbandingan ini ditunjukkan pada Gambar 8.

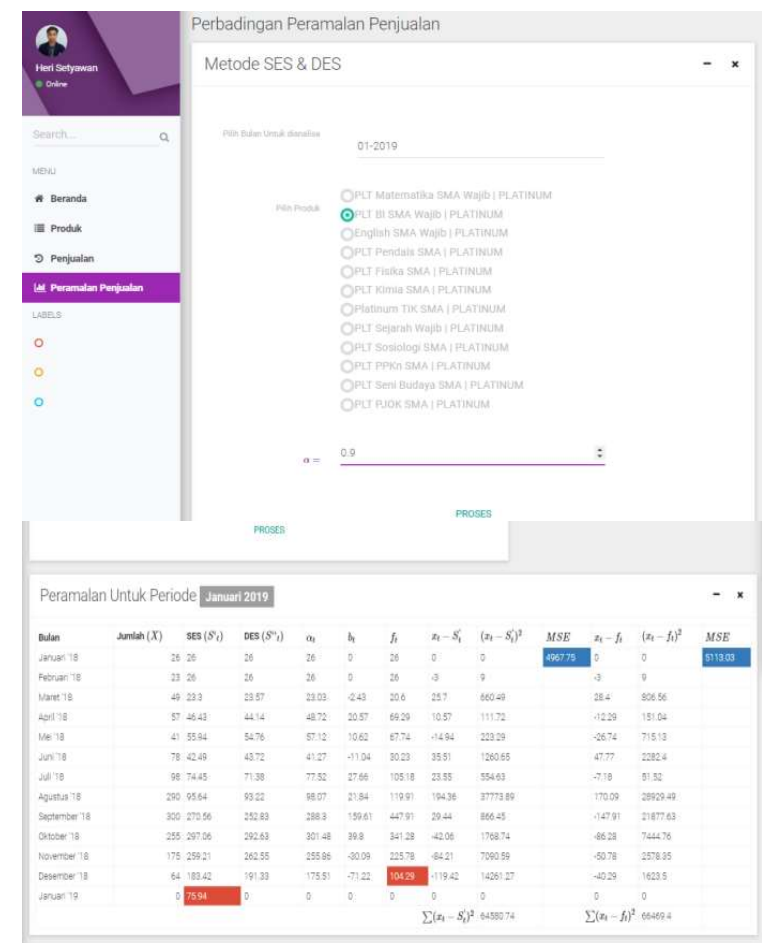

Gambar 8 Tampilan Halaman perbandingan 


\section{PENUTUP}

\subsection{Kesimpulan}

Berdasarkan masalah yang diuraikan dan pembahasan yang dilakukan penulis. Penulis dapat menyimpulkan beberapa hal dan saran, kesimpulan yang dapat ditarik dalam penelitian ini ialah:

1. Single Exponential Smoothing dan Double Exponential Smoothing dapat digunakan untuk melakukan peramalan jumlah penjualan di Toko Buku Sembilan. Hasil peramalan penjualan pada buku Bahasa Indonesia wajib mengunakan metode Single Exponential Smoothing pada bulan januari 2019 mengalami kenaikan dari periode sebelumnya yaitu 75,94 dan hasil peramalan penjualan mengunakan metode Double Exponential Smoothing pada bulan januari 2019 mengalami kenaikan dari periode sebelumnya yaitu 104,29.

2. Nilai error metode Single Exponential Smoothing dan Double Exponential Smoothing pada peramalan jumlah Penjualan Buku Bahasa Indonesia wajib di Toko Buku Sembilan adalah sebagai berikut.

a. Metode Single Exponential Smoothing Dengan (alpha $=0,9)$ didapatkan nilai MSE $=4967.75$

b. Metode Double Exponential Smoothing Dengan (alpha $=0,9$ ) didapatkan nilai MSE $=5113.03$

Dengan demkian metode peramalan yang paling efektif untuk melakukan peramalan jumlah penjualan pada Toko Buku Sembilan periode Januari 2018 - Januari 2019 adalah metode Single Exponential Smoothing karena memiki nilai error terkecil dari pada metode Double Exponential Smoothing.

\subsection{Saran}

Saran dalam pembuatan aplikasi ini ditujukan untuk mengembangkan sistem informasi peramalan penjualan Toko Buku Sembilan.

1. Dalam aplikasi ini, pemilihan nilai pemulusan diambil secara acak (trial/error). Sehingga untuk pengembangan selanjutnya dapat menampilkan nilai pemulusan secara menyeluruh.

2. Dalam penentuan perbandingan, aplikasi ini masih menggunakan sistem manual yaitu menentukan hasil perbandingan sendiri. Sehingga untuk pengembangan selanjutnya dapat membuat perbandingan otomatis yang ditentukan atau diproses oleh sistem.
3. Aplikasi perbandingan metode Single Exponential Smoothing dan Double Exponential Smoothing Pada Peramalan penjualan buku ini dapat ditambah persamaan ukuran statistik nilai kesalahan seperti Mean Error (MA), Mean Absolut Error (MAE) dan Sum Of Squared Error (MAPE).

\section{DAFTAR PUSTAKA}

[1] R. Utami and S. Atmojo, "Perbandingan Metode Holt Exponential Smoothing dan Winter Exponential Smoothing Untuk Peramalan Penjualan Souvenir," vol. 11, no. 2, pp. 123-130, 2017.

[2] Z. A. Farhath, B. Arputhamary, and L. Arockiam, "A Survey on Arima Forecasting Using Time Series Model," vol. 5, no. 8, pp. 104-109, 2016.

[3] R. T. Vulandari and E. Rokhmati, "Asymmetries Model Of Volatility Return Indonesian Sharia Stock Index With Exponential Generalized Autoregressive Conditional Heteroscedasticity," in Proceeding of International Conference On Research, Implementation And Education Of Mathematics And Sciences 2015, Yogyakarta State University, 2015, no. $17-19$ May 2015, pp. 97-100.

[4] D. T. Anggraeni, "Peramalan Harga Saham menggunakan Metode Autoregressive dan Web Scrapping pada Indeks Saham LQ45 dengan Python," Rabit J. Teknol. dan Sist. Inf. Univrab, vol. 5, no. 2, pp. 138-145, 2020.

[5] R. T. Vulandari, D. Remawati, Y. Retno, and $\mathrm{H}$. Wijayanto, "Perbandingan Prediksi Tinggi Muka Air Bendungan Wonogiri dengan Single Exponential Smoothing dan Brown' s Exponential Smoothing," J. Euclid, vol. 6, no. 2, pp. 167-176, 2018.

[6] E. Ostertagova and O. Ostertag, "Forecasting Using Simple Exponential Smoothing Method," Acta Electrotech. Inform., vol. 12, no. 3, pp. 62-66, 2012.

[7] S. Hansun, "A New Approach of Brown ' $s$ Double Exponential Smoothing Method in Time Series Analysis," Balk. J. Electr. Comput. Eng., vol. 4, no. 2, pp. 75-78, 2016.

[8] K. Margi and S. Pendawa, "Analisa dan Penerapan Metode Single Exponential Smoothing untuk Prediksi Penjualan pada Periode Tertentu (Studi Kasus : PT. Media Cemara Kreasi)," Pros. SNATIF, 
vol. 3, no. 1998, pp. 259-266, 2015.

[9] F. R. Perdana, Daryanto, and H. Wahyu, "Perbandingan Metode DES dengan TES pada Peramalan Penjualan Rokok," Jember, 2012.

[10] N. P. Y. Sukmarani, Statiswaty, and R. Ramadhan, "Penerapan Metode Exponential Smoothing pada Peramalan Penjualan dalam Penentuan Kuantitas Produksi Roti," J. Semant., vol. 2, no. 1, pp. 229-236, 2016. 